\title{
Carbon and nitrogen content of transparent exopolymer particles (TEP) in relation to their Alcian Blue adsorption
}

\author{
Anja Engel ${ }^{1, *, * *}$, Uta Passow ${ }^{2, *}$ \\ ${ }^{1}$ Institut für Meereskunde, 24109 Kiel, Germany \\ ${ }^{2}$ Marine Science Institute, University of California Santa Barbara, California 93106-6150, USA
}

\begin{abstract}
The carbon and nitrogen content of transparent exopolymer particles (TEP) was determined and related to the concentration of TEP as quantified by a colorimetrical method. TEP were produced in the laboratory from dissolved precursors by laminar or turbulent shear. Dissolved precursors were obtained by $0.2 \mu \mathrm{m}$ filtration from diatom cultures, with or without nutrient reduction, and from natural diatom populations. The relationship between carbon and TEP was significant, linear and species-specific. Carbon concentration of TEP derived from this relationship concurred with previous findings. Shortage of silicic acid or nitrate in the culture media had no effect on the carbon content of TEP. Molar C:N ratios of TEP were above the Redfield ratio, with a mean value of 26. It is suggested that the nitrogen fraction of TEP can be explained by adsorption of dissolved organic nitrogen (DON) onto TEP. Based on the newly established relationship, concentrations of TEP-derived carbon (TEP-C) were calculated for the Baltic Sea, the coastal Pacific, the North East Atlantic and the Northern Adriatic Sea.
\end{abstract}

KEY WORDS: Transparent exopolymer particles - TEP · POC $\cdot$ PON $\cdot$ Phytoplankton exudation · Coagulation · Carbon cycling

\section{INTRODUCTION}

The role of marine phytoplankton in the global carbon cycle is unique because they remove dissolved inorganic carbon from the upper ocean through photosynthesis and redirect it to the deep ocean through sedimentation. This process is referred to as the 'biological pump' and is driven mainly by coagulation of single phytoplankton cells into rapidly settling aggregates (Shanks \& Trent 1980, Asper et al. 1992). The formation of aggregates is enhanced in the presence of surface-active carbohydrates such as the recently-discovered transparent exopolymer particles (TEP) (Alldredge et al. 1993, Kiørboe \& Hansen 1993, Dam \&

\footnotetext{
${ }^{*}$ Present address: Alfred-Wegener-Institut für Polar- und Meeresforschung, PF 120161, 27515 Bremerhaven, Germany

**E-mail: aengel@awi-bremerhaven.de
}

Drapeau 1995, Logan et al. 1995, Engel 2000). TEP are polymeric gel particles that form abiotically from dissolved and colloidal organic matter by spontaneous assembly (Chin et al. 1998), bubble adsorption (Mopper et al. 1995, Zhou et al 1998, Mari 1999) or shear coagulation (Passow 2000). TEP are detected by staining with Alcian Blue, a cationic copper phthalocyanine dye that complexes carboxyl $\left(-\mathrm{COO}^{-}\right)$and half-ester sulfate $\left(\mathrm{OSO}_{3}^{-}\right)$reactive groups of acidic polysaccharides. The amount of Alcian Blue adsorption depends on the anion density of the exopolymer (Ramus 1977). To date, the concentration of TEP can be determined by microscopical enumeration and sizing (Passow \& Alldredge 1994) or colorimetrically (Passow \& Alldredge 1995). Ramus (1977), showed that the adsorption of Alcian Blue varies among different polysaccharides such as Agar, Carrageneen or natural exopolymers from macroalgae. He also showed that the 
amount of adsorbed Alcian Blue is directly related to the weight of the polysaccharide. The colorimetric method of Passow \& Alldredge (1995) is a semi-quantitative procedure that uses the relation between Alcian Blue staining capability and weight. A weight equivalent for the Alcian Blue adsorption is given by standardization with the exopolymer Gum Xanthan, because natural exopolymers are heterogenic.

One origin of polysaccharides in the sea is phytoplankton, especially through exudation by diatoms. Aluwihare \& Repeta (1999) showed that phytoplankton exudates closely resemble polysaccharides identified as a major constituent of the naturally occurring high molecular weight fraction of dissolved organic matter (DOM). The monosaccharide composition of these polysaccharides is similar to what is seen for TEP (Mopper et al. 1995, Aluwihare et al. 1997). Depending on their nutrient status, marine phytoplankton release between 3 and $40 \%$ of photosynthetic carbohydrates via exudation (Baines \& Pace 1991), with polysaccharides comprising the major fraction $(>75 \%)$ (Ittekot 1981, Myklestad et al. 1989, Biddanda \& Benner 1997).

It is generally assumed that DOM does not participate in the 'biological pumping' of carbon to the deep ocean because it does not sink. TEP, in contrast, interact with solid particles during coagulation and sediment in aggregates. TEP coagulation may therefore be a pathway for the sequestration of originally dissolved organic carbon to the deep ocean. Moreover, since TEP are essentially carbohydrate particles, their biogeochemistry should differ from organisms by an enrichment of carbon relative to the expected $\mathrm{C}: \mathrm{N}: \mathrm{P}$ ratio of 106:16:1 given by Redfield et al. (1963). Thus, sedimentation of TEP may even lead to selective export of carbon from surface waters. However, the question of how much TEP may contribute to the carbon flux in marine systems can not be answered until the carbon content of TEP and their C:N ratios are known. Mari (1999) provides the only estimate of the carbon and nitrogen content of TEP to date. He determined the size distribution of TEP produced by bubbling culture media of the marine diatom Thalassiosira weissflogii, prefiltered through GF/F filters, and calculated the carbon content of TEP, assuming a fractal scaling of TEP size to mass. His data indicate that TEP can contribute as much carbon to total particulate matter as conventional particles do. The determination of the carbon content of TEP by his method requires counting and sizing of individual TEP and is quite time consuming for large routine surveys.

Our motivation for this study was to examine whether the carbon and nitrogen content of TEP can be estimated by using a simple empirically established relationship in which TEP are quantified by the more convenient colorimetrical method of Passow \& Alldredge
(1995). We evaluated this newly established relationship between carbon concentration and Alcian Blue adsorption of TEP by an intercomparison with carbon concentrations of TEP that were determined after Mari (1999). Based on the conversion of colorimetrically determined TEP to carbon concentration we then give estimates of the carbon content of TEP in marine systems such as the Baltic and the Adriatic Sea, the open North East Atlantic and the coastal North Pacific Ocean.

\section{MATERIAL AND METHODS}

The determination of the elemental composition of TEP is delicate because, due to their high stickiness, TEP are usually attached to particles such as phytoplankton, bacteria and debris (Passow \& Alldredge 1994, Mari \& Kiørboe 1996). In order to analyze TEP, 2 major problems have to be addressed. Firstly, TEP have to be produced in a size range that allows the application of standard methods for $\mathrm{C}$ - and $\mathrm{N}$ - determination, e.g. quantitative retention on filters. Secondly TEP have to be isolated from other types of particles in seawater, especially phytoplankton and bacteria.

Formation of TEP. TEP were generated from dissolved precursors $(<0.2 \mu \mathrm{m})$ using shear (Passow 2000). This has the major advantage that phytoplankton and bacteria can be removed by filtration prior to the production of TEP. We used non-axcenic batch cultures of Thalassiosira weissflogii, Chaetoceros neogracilis and Coscinodiscus wailesii (CCMP 1818) grown in full or reduced F/2-media. Nitrogen or silicic acid concentrations were $30 \%$ of the full concentration in reduced media. In 3 experiments we also used natural assemblages of diatoms dominated by species of Thalassiosira spp., Rhizosolenia spp., Asterionella spp. and Chaetoceros spp. collected during the spring bloom in the Baltic Sea (Table 1). All cultures were grown at temperatures of 12 to $15^{\circ} \mathrm{C}$ with a daily $14: 10 \mathrm{~h}$ light:dark cycle of illumination at about $100 \mu \mathrm{E} \mathrm{cm}^{-2} \mathrm{~s}^{-1}$. Cultures were grown for $\sim 3 \mathrm{wk}$ in 21 polycarbonate bottles. Between 2 and 41 each were then filtered first through GF/F filters $(0.7 \mu \mathrm{m}$, Whatman) in order to remove diatom cells and subsequently through $0.2 \mu \mathrm{m}$ polycarbonate filters (Nucleopore) to remove all remaining particles including bacteria. TEP were generated either in Couette Chambers or by Tangential Flow Filtration (TFF), representing laminar and turbulent shear environments, respectively. When using the Couette Chamber assay, $2 \mathrm{l}$ of filtrate were incubated for 24 to $64 \mathrm{~h}$ in 2 horizontal Couette Chambers (Drapeau et al. 1994, Engel 2000), each with a filling capacity of $\sim 1 \mathrm{l}$, at a shear rate of $\mathrm{G}=8$ to $12 \mathrm{~s}^{-1}$. When using the TFF assay, $4 \mathrm{l}$ of $0.2 \mu \mathrm{m}$ filtrate were cycled through a TFF Chamber (Filtron Ultrasette) with a $0.16 \mu \mathrm{m}$ membrane for $24 \mathrm{~h}$. During TFF, substances 
Table 1. Diatom species that provided precursor material used for formation of TEP and setup of experiments

\begin{tabular}{|lcclcc|}
\hline Species & Culture media & $\begin{array}{c}\text { No. of } \\
\text { assays }\end{array}$ & TEP production & $\begin{array}{c}\text { Incu- } \\
\text { bation } \\
\text { time (h) }\end{array}$ \\
\hline Natural diatom bloom & No nutrient addition & 3 & Couette chamber & 64 \\
Chaetoceros gracilis & $\mathrm{f} / 2$ & 4 & Couette chamber & 64 \\
Thalassiosira weissflogii & $\mathrm{f} / 2$ & 4 & Couette chamber & 64 \\
Thalassiosira weissflogii & N-reduced & 1 & Ultrafiltration & 24 \\
Thalassiosira weissflogii & Si-reduced & 1 & Ultrafiltration & 24 \\
Thalassiosira weissflogii & N-reduced & 4 & Couette chamber & 24 \\
Thalassiosira weissflogii & Si-reduced & 1 & Couette chamber & 24 \\
Coscinodiscus wailesii & N-reduced & 2 & Ultrafiltration & 24 \\
Coscinodiscus wailesii & N-reduced & 6 & Couette chamber & 24 \\
Coscinodiscus wailesii & Si-reduced & 2 & Couette chamber & 24 \\
\hline
\end{tabular}

Intercomparison of estimates for the carbon content of TEP. Carbon concentrations of TEP, obtained from the conversion of colorimetrically determined TEP (TEP-C $\mathrm{C}_{\text {color }}$ ), were compared to carbon concentrations determined from size frequency distributions (TEP-C $\mathrm{SFD}_{\mathrm{SP}}$ ). For comparison, we used 90 samples collected during a field study in the Baltic proper in summer 1999, where TEP were measured both colorimetrically and microscopically. These samples included seawater collected from the upper $20 \mathrm{~m}(\mathrm{n}=40)$, samples collected from the upper 20 $\mathrm{m}$ and enriched in material $>0.16 \mu \mathrm{m}$ using TFF ( $\mathrm{n}=32$ ), and aggregates

larger than the poresize of the membrane are trapped within the turbulent motion of the fluid. Since both laminar and turbulent shear produce TEP, TEP precursors coagulated during the filtration procedure and accumulated in the retentate fraction. We cycled the filtrate together with the retentate for $\sim 20 \mathrm{~h}$ and concentrated TEP for $4 \mathrm{~h}$ to a final volume of $2 \mathrm{l}$.

Measurement of carbon, nitrogen and TEP. After generating TEP, all samples were analyzed for carbon, nitrogen and TEP concentration. TEP were measured colorimetrically (Passow \& Alldredge 1995) from 100 to $300 \mathrm{ml}$, with at least 2 replicates each. Concentrations of TEP are given in the unit 'Xanthan Equiv. $\mathrm{l}^{-1}$ '. This unit relates the amount of adsorbed Alcian Blue to the equivalent weight of the polysaccharide Gum Xanthan, which is used as a standard.

Silver filters (Poretics) were used for the CHN-analysis of TEP, instead of the more common GF/F filters, because the pore size of silver filters $(0.45 \mu \mathrm{m})$ is similar to the pore size of the polycarbonate filters $(0.4 \mu \mathrm{m})$ that are used in the standard protocol for TEP determination (Passow \& Alldredge 1995). Between 200 and $400 \mathrm{ml}$ of sample was filtered for CHN analyses (CHNO-Rapid, CHN-Analyzer CE 440, Leeman Labs Inc.) with all filters prepared at least in duplicate. All filters were frozen until analysis. All materials in contact with the sample were either autoclaved or acid $(10 \% \mathrm{HCl})$ rinsed. Blank silver filters were prepared for each filtration series.

Particulate organic carbon (POC) in the field studies of the Baltic Sea, the Northern Adriatic Sea, the coastal North Pacific and the open Northeast Atlantic was measured with a CHN analyzer (CHN-O-Rapid, CHNAnalyzer CE 440, Leeman Labs Inc.) from samples filtered onto precombusted GF/F glassfibre filters. The determination of TEP in those studies was performed colorimetrically (Passow \& Alldredge 1995).
$>0.5 \mathrm{~mm}(\mathrm{n}=18)$ formed in a roller table from seawater taken at 0,4 , and $9 \mathrm{~m}$ depths. TEP were determined colorimetrically (Passow \& Alldredge 1995) from duplicate polycarbonate filters $(0.4 \mu \mathrm{m})$ onto which 5 to $100 \mathrm{ml}$ samples were filtered. TEP were also determined microscopically (Passow \& Alldredge 1994) from TEP slides (3 to $20 \mathrm{ml}$ ) prepared in duplicate within $1 \mathrm{~h}$ of sampling. Slides were transferred to a compound light microscope and screened by a Panasonic color video camera with $400 \times$ magnification. About $2 \times 25$ frames per slide were chosen in a cross section and digitized on a Macintosh PPC with an optical resolution of $0.17 \mu^{2}$ per pixel. TEP were enumerated and sized semi-automatically using the public domain NIH Image program, developed at the US National Institutes of Health and available at: http:// rsb.info.nih.gov/nih-image/. The equivalent spherical diameter (ESD) of individual TEP was calculated from measurements of the area assuming the symmetry of a sphere (Mari \& Kiørboe 1996). Only TEP that did not touch the edge of the frame and contained at least 5 pixels equivalent to a minimum TEP size of $0.5 \mu \mathrm{m}$ were counted for TEP-carbon. TEP-C was calculated using the empirical relationship between colorimetrically determined TEP concentration and carbon concentration described below. TEP-C was also calculated from the microscopical analysis using the size-dependent relationship proposed by Mari (1999): TEP-C $=0.25 \times 10^{-6}$ $r^{2.55}$, with TEP-C in $\mu$, and $r$ in $\mu \mathrm{m}$.

\section{RESULTS}

\section{The carbon and nitrogen content of TEP}

It is feasible to test whether or not the increase in colorimetrically determined TEP is concomitant with a linear increase in carbon because it has been shown 
that the adsorption of Alcian Blue is related to the weight of the polysaccharide. Therefore, a linear regression was calculated using data from all experiments (Fig. 1A):

Carbon $\left[\mathrm{\mu g} \mathrm{l}^{-1}\right]=$

$(0.75 \pm 0.05)\left[\right.$ TEP; $\mu$ g Xant. Equiv. $\left.1^{-1}\right]+(110 \pm 83)$

The regression line does not cross the origin, but intersects the $y$-axis at $110 \mu \mathrm{gC} \mathrm{l}^{-1}$. However, this offset is not significant, since the range of given carbon concentrations is 1 to 2 orders of magnitude larger. It may simply indicate contamination by non-TEP substances, which showed a high variability between the experiments. The slope of the regression $\mathrm{f}^{\prime}(\mathrm{C})=\mathrm{d}[\mathrm{C}] / \mathrm{d}[\mathrm{TEP}]$ is significant $(\mathrm{p}<0.001)$ with a standard deviation of $<7 \%$. We therefore consider the slope of the regression
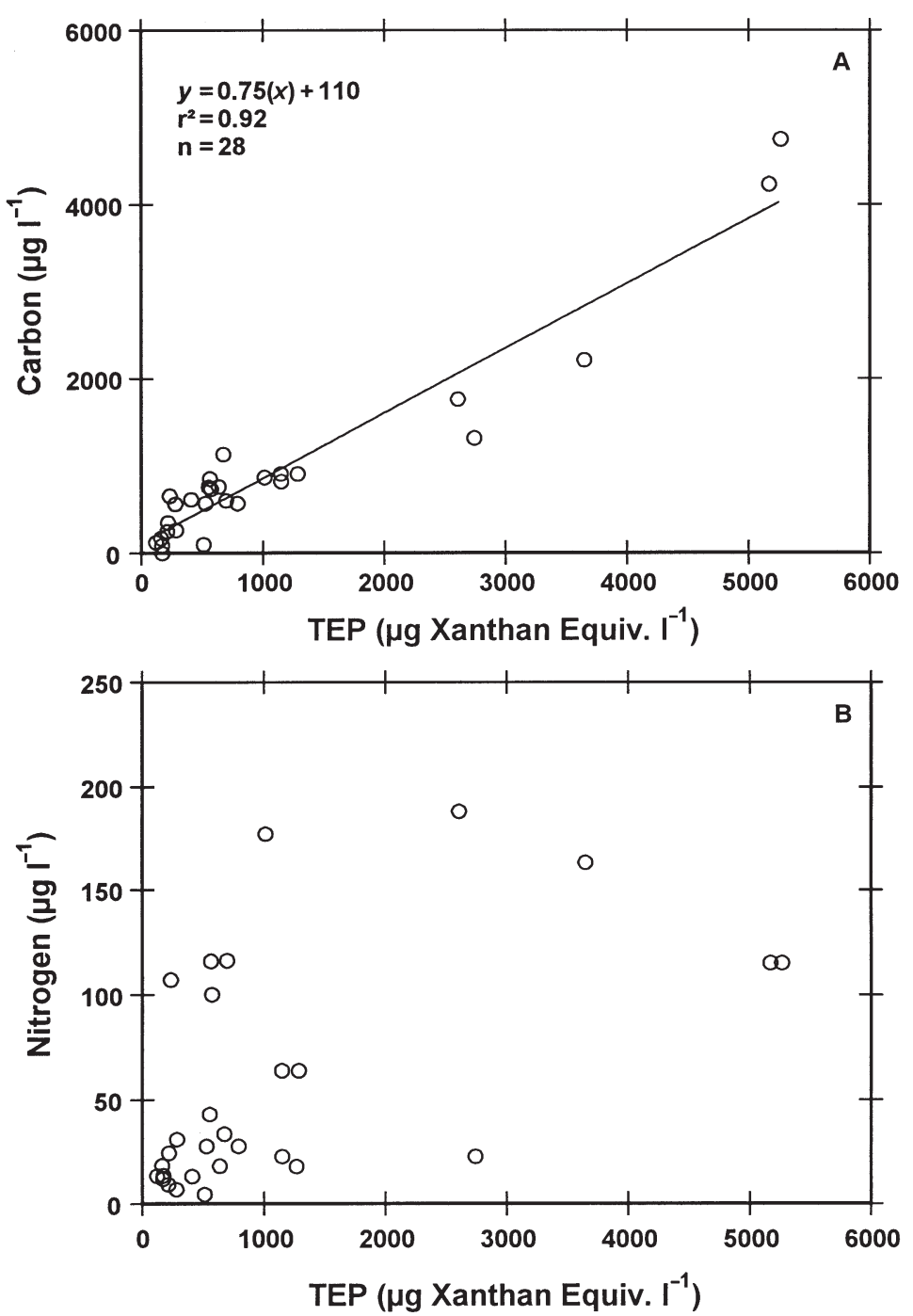

Fig. 1. Relationship between colorimetrically determined TEP and (A) carbon or (B) nitrogen based on all experimental data as a reliable first-order approximation of the increase of carbon with an increase in TEP, which is later used for calculations of TEP derived carbon (TEP-C). No significant linear relationship between nitrogen and TEP was found (Fig. 1B), indicating that the nitrogen fraction within TEP was more variable than the carbon fraction, or that nitrogen was contained in the non-TEP substances.

Slopes $\mathrm{f}^{\prime}(\mathrm{C})_{\text {spec. }}$ were also calculated individually for each of the different diatom assemblages that provided precursor material of TEP (Table 2); note that these are subsamples of the combined data that were used to determine the 'overall' slope $\mathrm{f}^{\prime}(\mathrm{C})$. Slopes were significantly different in most cases $\left(t\right.$-test, $\mathrm{H}_{0}$ : $\mathrm{f}^{\prime}(\mathrm{C})_{\text {spec. } 1}=$

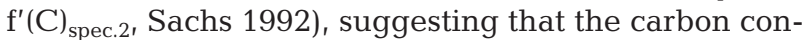
tent of TEP is species-specific (Table 2). Nevertheless, species-specific differences were small enough not to invalidate the overall relationship. A mean molar C:N ratio of 25.7 (Standard deviation $\mathrm{SD}=21.3$, range 5.6-94) was calculated using data of all assays $(n=28)$. No significant interspecific differences in the C:N ratio of TEP, and no relationship between nitrogen or silicate limitation in the culture media and the $\mathrm{C}: \mathrm{N}$ ratio of TEP were observed. Carbon to nitrogen ratios of TEP derived from natural diatom assemblages that grew without nutrient addition were found to be uniformly high $(43 \pm 4.3)$.

\section{Intercomparison of TEP-C determination}

TEP concentrations within the samples from the Baltic proper in 1999 extended across 4 orders of magnitudes, ranging from $6.4 \times 10^{1}$ to $5.7 \times 10^{4} \mu$ Xanthan Equiv. $1^{-1}$, regarding colorimetrically determined TEP. Volume fraction of microscopically enumerated and sized TEP ranged from $6 \times 10^{-1}$ to $4.6 \times 10^{3} \mathrm{ppm}$. Carbon concentrations calculated from size frequency distribution of TEP, after Mari (1999), ranged from $3.5 \times 10^{1}$ to

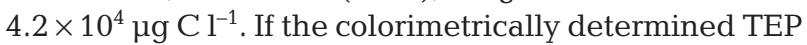
can be converted to carbon concentration, as suggested above, then they should also be linearly related to carbon concentrations of TEP calculated from size frequency distributions. Indeed, the relationship between TEP concentration, derived from the amount of Alcian Blue adsorbed, and carbon concentration of TEP as determined from size frequency distributions (TEP-C $\mathrm{SFD}_{\mathrm{SF}}$ ) was highly significant and yielded (Fig. 2):

$$
[\mathrm{TEP}-\mathrm{C}]_{\mathrm{SFD}}=0.60 \pm 0.03[\mathrm{TEP}]
$$

with TEP concentration given in Xanthan Equiv. $\mathrm{l}^{-1}(\mathrm{p}<$ $0.001,95 \%$ confidence interval for the slope $\mathrm{f}^{\prime}(\mathrm{C})_{\mathrm{SFD}}$ : 0.54 to 0.66$)$. The slope of the regression $\mathrm{f}^{\prime}(\mathrm{C})_{\mathrm{SFD}}$ was lower than the 'overall' conversion factor of 0.75 suggested from Eq. (1). However, $\mathrm{f}^{\prime}(\mathrm{C})_{\mathrm{SFD}}$ was not signifi- 
Table 2. Slopes for relationship between carbon and colorimetrically determined TEP concentration, calculated individually for each species and for the natural diatom population, as well as statistics showing that slopes differed significantly between species. Test of slopes $\left(H_{0}\right.$, $\mathrm{f}^{\prime}(\mathrm{C})_{\text {spec. } 1}=\mathrm{f}^{\prime}(\mathrm{C})_{\text {spec. } 2 i} H_{1}, \mathrm{f}^{\prime}(\mathrm{C})_{\text {spec. } 1} \neq \mathrm{f}^{\prime}(\mathrm{C})_{\text {spec } .2)}$ performed according to $t$-statistics of Sachs (1992). $\neq, H_{0}$ rejected at $\mathrm{p}<0.05 ; \mathrm{n}$, number of assays

\begin{tabular}{|c|c|c|c|c|c|c|c|}
\hline Species & $\mathrm{n}$ & $\begin{array}{c}\text { slope } \\
\mathrm{f}^{\prime}(\mathrm{C})_{\text {spec. }}\end{array}$ & $\underset{<}{p_{\text {slope }}}$ & $\begin{array}{c}\text { Chaetoceros } \\
\text { gracilis }\end{array}$ & & & \\
\hline $\begin{array}{c}\text { Chaetoceros } \\
\text { gracilis }\end{array}$ & 4 & $0.53 \pm 0.14$ & 0.1 & - & $\begin{array}{c}\text { Natural } \\
\text { population }\end{array}$ & & \\
\hline $\begin{array}{l}\text { Natural } \\
\text { population }\end{array}$ & 3 & $0.74 \pm 0.085$ & 0.1 & $\mathrm{p}<0.1$ & - & $\begin{array}{c}\text { Thalassiosira } \\
\text { weissflogii }\end{array}$ & \\
\hline $\begin{array}{c}\text { Thalassiosira } \\
\text { weissflogii }\end{array}$ & 11 & $0.51 \pm 0.061$ & 0.001 & $\neq$ & $\neq$ & - & $\begin{array}{c}\text { Coscinodiscus } \\
\text { wailesii }\end{array}$ \\
\hline $\begin{array}{c}\text { Coscinodiscus } \\
\text { wailesii }\end{array}$ & 10 & $0.88 \pm 0.24$ & 0.01 & $\neq$ & $\neq$ & $\neq$ & - \\
\hline
\end{tabular}

\section{TEP-C in various marine systems}

Average carbon concentration due to TEP in the upper water column of different marine systems ranged from a value of $27 \mu \mathrm{g} \mathrm{C} \mathrm{l}^{-1}$ during fall in the open Atlantic to $769 \mu \mathrm{g}$ $\mathrm{C}^{-1}$ in spring in the Adriatic (Table 3), implying that the contribution of TEP to the carbon pool is significant. A direct relationship between TEP-C and POC in situ, however, was found only during the diatom spring bloom in the

cantly different ( $t$-test, Sachs 1992) from the conversion factor for Thalassiosira weissflogii $(0.51 \pm 0.061$, Table 2$)$, which was the species used by Mari (1999) to derive the relationship for size frequency distributions. Nevertheless, the above relationship (Eq. 2) is a first order approximation over 4 orders of magnitude and individual data points deviate considerably from this regression. Even with a conversion factor of 0.51 the ratio between TEP-C $C_{\text {SFD }}$ and TEP-C $C_{\left(f^{\prime}(C)=0.51\right)}$ ranged from 0.3 to 2.7 .

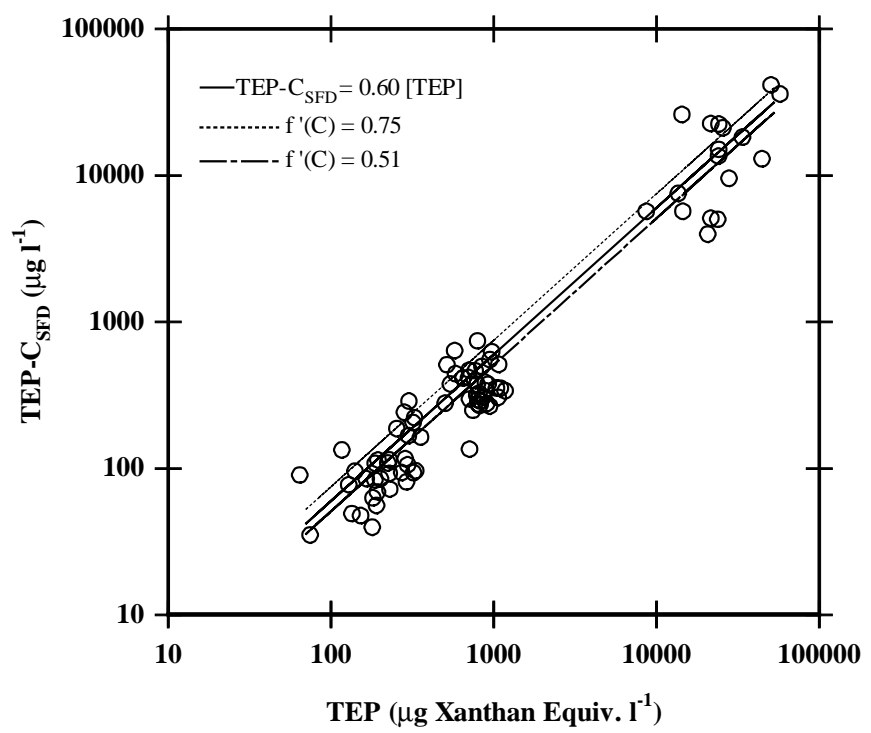

Fig. 2. Carbon concentrations of TEP calculated from microscopically enumerated and sized TEP (TEP-C $\mathrm{C}_{\mathrm{SFD}}$ ) and related to colorimetrically determined TEP $\left(r^{2}=0.80, n=90\right)$. Slope of this relationship is not significantly different from the slope $\mathrm{f}^{\prime}(\mathrm{C})_{\text {spec. }}=0.51$ calculated for Thalassiosira weissflogii during this study. TEP-C concentrations that would be attained with overall conversion factor of $\mathrm{f}^{\prime}(\mathrm{C})=0.75$ also indicated
Kiel Bight, a coastal Baltic Sea location $(p<0.01)$ (Fig. 3). TEP-C determined for the Baltic proper in summer 1999 varied widely compared to a relatively narrow range of POC concentration. In contrast, high variability of POC was observed at the open East Atlantic Ocean, where the variability in TEP-C was quite small.

\section{DISCUSSION}

\section{The carbon and nitrogen content of TEP}

Acidic polysaccharides, or mucopolysaccharides, are major components of extracellular polymeric substances released by various organisms such as bacteria, phytoplankton, macroalgae or even fish (Decho 1990, Hoagland et al. 1993). The monomeric composition of marine mucopolysaccharide is diverse (see Decho 1990, Hoagland et al. 1993 or Leppard 1995 for details) and even among diatoms the chemical composition of released substances varies both with species and physiological stage (Myklestad 1977). The exact chemical composition of TEP is not known, but they are presumably also a chemically diverse group of particles. Consequently, the number of anionic groups per unit weight of TEP, i.e. their staining capacity, may vary depending on their origin. In marine waters the widespread occurrence of TEP has been attributed especially to diatoms and Phaeocystis (Alldredge et al. 1993, Passow \& Wassmann 1994, Hong et al. 1997, Krembs \& Engel 2001). Myklestad et al. (1972) found that the exopolysaccharides of Chaetoceros affinis consisted mainly of fucose, rhamnose and arabinose. Moreover, the intracellular polysaccharide composition was markedly different from that of the exopolymers, indi- 
Table 3. Mean estimates of particulate organic carbon (POC) and TEP-carbon (TEP-C) at various marine sites. Observations are water column values averaged over surface mixed layer: ${ }^{*} 0-10 \mathrm{~m}_{i}{ }^{* *} 0-30 \mathrm{~m}$ or ${ }^{* * *}$ from $\mathrm{chl}$ a maximum. TEPvolume fraction (ppm) calculated assuming carbon density $0.017 \mathrm{~kg} \mathrm{l}^{-1}$ for mean TEP with $\mathrm{r}=15.4 \mu \mathrm{m}$ (see text for details)

\begin{tabular}{|c|c|c|c|c|}
\hline Area & $\begin{array}{l}\text { No. of } \\
\text { field } \\
\text { stations }\end{array}$ & $\begin{array}{c}\text { Measured } \\
\text { POC } \\
\left(\mu g \mathrm{l}^{-1}\right) \\
\text { mean } \pm \mathrm{SD}\end{array}$ & $\begin{array}{c}\text { Calculated } \\
\text { TEP-C } \\
\left(\mu \mathrm{l}^{-1}\right) \\
\text { mean } \pm \mathrm{SD}\end{array}$ & $\begin{array}{l}\text { Approximated } \\
\text { TEP-volume } \\
\text { fraction } \\
(\mathrm{ppm})\end{array}$ \\
\hline $\begin{array}{l}\text { (1) Coastal Pacific* } \\
(01-12 / 1996)\end{array}$ & 29 & $272 \pm 137$ & $140 \pm 79$ & 8 \\
\hline $\begin{array}{l}\text { (2) Coastal Baltic Sea }{ }^{*} \\
\text { (03-04/1996, diatom bloom) }\end{array}$ & ) & $533 \pm 178$ & $119 \pm 30$ & 7 \\
\hline $\begin{array}{l}\text { (3) Central Baltic Sea* } \\
\text { (06/1999) }\end{array}$ & 11 & $414 \pm 37$ & $169 \pm 46$ & 10 \\
\hline $\begin{array}{l}\text { (4) North East Atlantic** } \\
\text { (06-07/1996, Meteor 36/2) }\end{array}$ & 10 & $238 \pm 100$ & $40 \pm 13$ & 2 \\
\hline $\begin{array}{l}\text { (5) North East Atlantic }{ }^{* * *} \\
\text { (09-10/1996, Meteor 36/5) }\end{array}$ & 17 & $116 \pm 55$ & $27 \pm 9.5$ & 2 \\
\hline $\begin{array}{l}{ }^{(6)} \text { Northern Adriatic Sea ** } \\
(04 / 1996)\end{array}$ & 3 & $744 \pm 215$ & $769 \pm 285$ & 44 \\
\hline \multicolumn{5}{|c|}{$\begin{array}{l}\text { Data sources: }{ }^{(1)} \text { Passow et al. }(2001),{ }^{(2)} \text { TEP data Kraus }(1997),{ }^{(3)} \text { Engel (in } \\
\text { press), }{ }^{(4)} \text { Engel et al. }(1997),{ }^{(5)} \text { Engel et al. (unpubl. data), }{ }^{(6)} \text { Engel (in press) }\end{array}$} \\
\hline
\end{tabular}

In this study the carbon content of TEP produced from growth media of different diatom species was approximated from the Alcian Blue staining capacity with a single linear relationship. Among the diatom species examined, the slope $\mathrm{f}^{\prime}(\mathrm{C})_{\text {spec. }}$ varied from 0.51 to 0.88 . Thus, the chemical composition of the exopolysaccharides and consequently the carbon content of TEP seems to be species-specific and may vary in natural water samples. Ramus (1977) showed that the adsorption of Alcian Blue is a measure for the weight of an exopolysaccharide and that the relationship between Alcian Blue adsorption and weight is polysaccharide-specific. Hence, the linear relationship between colorimetricallydetermined TEP and carbon, implies that carbon is also directly related to the weight of TEP, and can therefore be considered a conservative constituent.

Nitrogen, in contrast, was not signif-

cating that exopolysaccharides were not a leakage product. Similar results were obtained by Mopper et al. (1995) and Zhou et al. (1998), who found that surface active polysaccharides and TEP formed by bubble coagulation were enriched in the desoxysugars fucose and rhamnose.

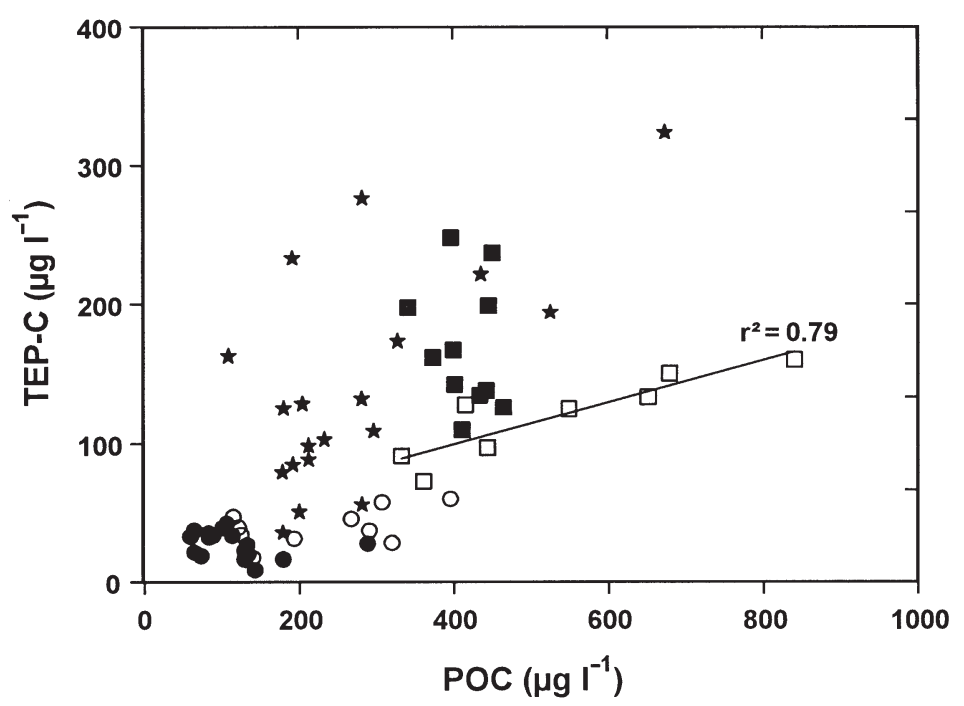

Fig. 3. Relationship between TEP-carbon (TEP-C) and particulate organic carbon (POC) at different marine sites: $\square$, coastal Baltic Sea (diatom spring bloom 1996); $\mathbf{\square}$, central Baltic Sea (Summer 1999); O, North Atlantic (Spring 1996); •, Eastern North Atlantic (Autumn 1996); ^, coastal Pacific (1996) icantly related to TEP concentrations. Nitrogen in polysaccharides is contained in the monomers $\mathrm{N}$-acetylglucosamine and $\mathrm{N}$-acetyl-galactosamine for example, but amino acids (Schuster et al. 1998) and proteins (Hoagland et al. 1993, Mopper et al. 1995) have also been isolated from diatom exopolymers. Protein particles from seawater samples stainable with Coomassie Blue (Coomassie Blue Stainable Particles, CSP) are, for example, frequently associated with TEP (Long \& Azam 1996). The fact that the nitrogen content of TEP was highly variable suggests that it probably depends on the adsorption of dissolved and colloidal nitrogen present in the culture media, rather than on nitrogen contained in the polymeric matrix of TEP themselves.

Exudation of dissolved nitrogen components, mainly amino acids, has been measured in diatom cultures during all growth stages (Admiraal et al. 1986, Myklestad et al. 1989). Myklestad et al. (1989) showed that extracellular amino acids (AA) from the diatom Chaetoceros affinis had a $\mathrm{C}: \mathrm{N}$ ratio of 2.6 by weight. Assuming that all nitrogen measured on silver filters during this study originated from adsorbed AA, we subtracted AA-Carbon $\left(\mathrm{C}_{\mathrm{AA}}\right)$ from total carbon measured on silver filters (Fig. 4). The corrected regression of $\left(\left[\mathrm{C}_{\text {total }}\right]-\left[\mathrm{C}_{\mathrm{AA}}\right]\right)$ vs TEP yielded a slope of $\mathrm{f}^{\prime}(\mathrm{C})=0.69 \pm$ 0.05 ( $p<0.001)$, not significantly different from the former slope without $\mathrm{C}_{\mathrm{AA}}$ correction. However, the $y$-intercept of the regression was no longer significantly different from zero. This suggests that the nitrogen measured was due to adsorption of amino acids either 


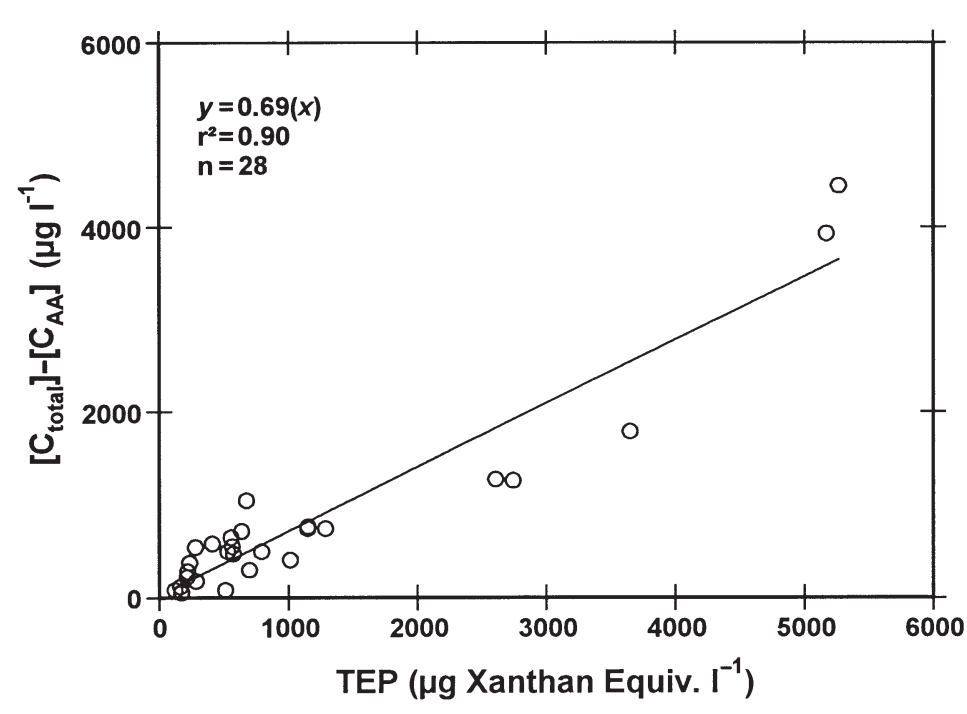

Fig. 4. Relationship between total carbon concentrations $\left(\mathrm{C}_{\text {total }}\right)$ minus amino acid carbon concentrations $\left(\mathrm{C}_{\mathrm{AA}}\right)$ to the colorimetrically determined TEP concentration, based on data of all experiments. $\mathrm{C}_{\mathrm{AA}}$ calculated assuming that all nitrogen measured with TEP was contained in amino acids

on TEP or on the filter and that amino acids were also responsible for the observed background concentration of carbon. Consequently, the C:N ratios of TEP may depend on the adsorption and coagulation with nitrogen containing compounds. We expect that the mean C:N ratio of 26, calculated largely for TEP from cultures, is a lower estimate and that the $\mathrm{C}: \mathrm{N}$ ratios of TEP produced in natural sea waters are likely to be higher.

\section{Comparison of TEP-C methods}

Theoretical considerations suggest systematic differences in the TEP-C content as estimated from microscopically (TEP-C $\mathrm{SFD}_{\mathrm{SF}}$ ) and colorimetrically determined TEP (TEP-C $\mathrm{C}_{\text {color }}$ ), which are based on methodological differences in the measurement of TEP. The colorimetrical method measures all material that adsorbs Alcian Blue, including discrete TEP but also the mucilaginous coating of several bacteria and algae, e.g. filamentous Cyanobacteria like Nodularia spp. and pennate diatoms, which are common in field samples originating from the Baltic Sea. Additionally, while the lower size boundary of TEP in size measurements is systematically fixed due to, for example, the optical resolution of the image analysis system, the colorimetrical methods also detect TEP $<0.4 \mu \mathrm{m}$, which did not pass through the pores of the filter. Thus the concentration of colorimetrically determined TEP should be higher than that of microscopically sized TEP. Moreover, the microscopical analysis requires quantitative transfer of TEP from the filter to the slide and loss during this transfer would further reduce the estimate for TEP. Problems associated with the calculation of the size of a 3-dimensional polymer from 2-dimensional size measurements after filtration are possibly most important. The calculations of equivalent spherical volumes and the respective radius from area measurements may be inaccurate and biased also by changes in the consistency of the polymer gel.

Despite these methodological differences between colorimetrical and microscopical measurements of TEP, which are likely to impact carbon estimates, the overall accordance of both methods for the samples of the Baltic Sea was convincing. The observation that TEP-C $\mathrm{SFD}_{\mathrm{S} D}$ was directly related to colorimetrically determined TEP, indicates once more that Alcian Blue adsorption is a direct measure for the mass of TEP. Although there was a good accordance between the methods, we like to emphasize once more that both methods were derived using diatoms, mostly in cultures, and that the true carbon content of naturally occurring TEP may differ.

The TEP to carbon conversion factor $\mathrm{f}^{\prime}(\mathrm{C})$ presented here can also be evaluated by estimating the TEP volume fraction necessary to provide the calculated amount of carbon, and comparing these results with TEP volumes for naturally occurring TEP as given in the literature. This was done as follows: assuming that the carbon content of individual, spherical TEP is size dependent (Mari 1999), the size specific carbon density of TEP $\left(\rho_{\text {TEP-C, }} \mu \mathrm{gC} \mu \mathrm{m}^{-3}\right)$ is:

$$
\rho_{\text {TEP-C }}=\left(0.25 \times 10^{-6} \mathrm{r}^{2.55}\right) /\left(4 / 3 \pi \mathrm{r}^{3}\right)
$$

with the factor $0.25 \times 10^{-6}$ in the empirically established relationship from Mari (1999) having an apparent unit of $\mu \mathrm{gC} \mu \mathrm{m}^{-2.55}$. Assuming further that the diameter of individual TEP is between 0.40 and $100 \mu \mathrm{m}$ (larger TEP are rare in natural samples), a median carbon density is attained at a TEP size of $\mathrm{m}^{*}$ :

$$
0.5 \int_{0.2}^{50} \rho_{\mathrm{TEP}-\mathrm{C}} \mathrm{dr}=\int_{\mathrm{m}^{*}}^{50} \rho_{\mathrm{TEP}-\mathrm{C}} \mathrm{dr}
$$

Solving Eq. (4) for $\mathrm{m}^{*}$ leads to a median carbon density of $1.74 \times 10^{-2} \mathrm{~kg} \mathrm{l}^{-1}$ at a size of $\mathrm{r}=15.4 \mu \mathrm{m}$. With this theoretical median carbon density, a TEP volume fraction as low as $2 \mathrm{ppm}$ in the open Atlantic and as high as $44 \mathrm{ppm}$ in the Adriatic Sea was estimated from TEP-C data, which were calculated from colorimetrical determinations (Table 3). Volume fractions of TEP approximated for the surface layer of the Baltic Sea were $\sim 7$ to 10 ppm. For comparison, Mari \& Burd (1998) directly measured TEP volume fraction and gave a range of 3 to 310 ppm for the Baltic Sea, with a mean of 14 ppm for the surface layer. Engel (2000) observed TEP volume 
fractions with a maximum of $4 \mathrm{ppm}$ during the decline of a diatom bloom but counted only TEP $>8 \mu \mathrm{m}$ and thus missed a large fraction of TEP that is retained on polycarbonate filters used for TEP analysis.

\section{Implications for the marine carbon cycling}

TEP-C comprised a significant carbon fraction at all sites examined, being lowest in the open North-East Atlantic in autumn and highest in the Adriatic Sea, where TEP-C concentration was comparable to POC. However, TEP-C concentrations were quite low when compared to dissolved organic carbon (DOC). DOC concentrations are $\sim 1$ order of magnitude higher in these regions (e.g. Osteroth et al. 1985, Baltic Sea; Williams et al. 1993, coastal Pacific off California; Pettine et al. 1999, Northern Adriatic Sea; Kähler \& Koeve 2001, North-East Atlantic). It can be assumed that some varying fraction of TEP-C is measured as DOC because TEP cannot be retained quantitatively on GF/F filters. Using size fractionated filtration, Passow \& Alldredge (1995) observed that $>50 \%$ of TEP were lost when $0.6 \mu \mathrm{m}$ filters were used instead of $0.2 \mu \mathrm{m}$ filters.

Biddanda \& Benner (1997) observed that C:N ratios of DOM in various phytoplankton cultures ranged from 4.1 for Synechococcus to 14.1 for Skeletonema, but that the high molecular weight fraction, which consisted mainly of polymeric carbohydrates, had higher and more uniform $\mathrm{C}: \mathrm{N}$ ratios between 19.3 and 25.1. TEP, which form from dissolved polysaccharides, exhibit a similar accumulation of carbon, with an average C:N ratio of 26, or even higher as discussed above. Particulate organic matter (POM) in the surface ocean often follows 'Redfield-stoichiometry' (e.g. Williams 1995, Kepkay et al. 1997), although regressions of POC vs PON with Redfield-type slopes may have significant $y$-intercepts (Copin-Montegut \& Copin-Montegut 1983), indicating that some fraction of POC does not relate to PON. There are also observations of elevated C:N ratios in phytoplankton cultures (Sakshaug \& HolmHansen 1977), experimental systems (Antia et al. 1963) and in the field (Daly et al. 1999), which have mainly been interpreted as an increase of carbon over nitrogen, within the cells, under nitrogen depletion. As some fraction of TEP is collected on GF/F filters used for the determination of POM, it must be assumed that the average elemental concentration ratio of POM, which comprise a plethora of different kinds of particles, includes carbon-rich particles such as TEP. We speculate that a potential increase of TEP over conventional particles, as observed during the decline of a diatom bloom in a laboratory study (Engel 2000), will be another factor responsible for elevated C:N ratios.
Abiotically formed exopolymeric particles such as TEP differ fundamentally from biotic particles such as phytoplankton, because the production of exopolysaccharides is not directly related to the availability of nitrogen and phosphorus (Myklestad 1977, Myklestad et al. 1989, Biddanda \& Benner 1997). The release of extracellular carbohydrates by phytoplankton has been attributed to an imbalance in the availability of light and nutrients (Wood \& Van Valen 1990), and TEP production also appears as a kind of cellular carbon overflow whenever nutrient acquisition limits biomass production but not photosynthesis (Engel in press). Although TEP do not sink gravitationally, they are exported as aggregates (Alldredge et al. 1993, Engel \& Schartau 1999, Passow et al. 2001). The loss of TEP from the upper ocean may thus be viewed as a mechanism to remove organic carbon whose production did not follow the Redfield stochiometry. Moreover, the abiotic formation and sedimentation of TEP represents a pathway for the removal of DOM from the euphotic zone, which is often neglected. Since the current database is far from being sufficient to estimate the role of TEP for the cycling of carbon in the ocean, we hope that TEP measurement will be included in future field studies.

Acknowledgements. We thank Alice Alldredge, Iris Kriest \& Markus Schartau for intensive discussions and fruitful suggestions for improvements of former versions of the manuscript. Both authors were funded by the Deutsche Forschungsgemeinschaft (DFG).

\section{LITERATURE CITED}

Admiraal W, Peletier H, Laane RWPM (1986) Nitrogen metabolism of marine planktonic diatoms; excretion, assimilation and cellular pools of free amino acids in seven species with different cell size. J Exp Mar Biol Ecol 98:241-263

Antia NJ, McAllister CD, Parsons TR, Stephens K, Strickland JDH (1963) Further measurements of primary production using a large-volume plastic sphere. Limnol Oceanogr 8: 166-183

Alldredge AL, Passow U, Logan BE (1993) The abundance and significance of a class of large, transparent organic particles in the ocean. Deep-Sea Res 40:1131-1140

Aluwihare LI, Repeta DJ (1999) A comparision of the chemical characteristics of oceanic DOM and extracellular DOM produced by marine algae. Mar Ecol Prog Ser 186:105-117

Aluwihare LI, Repeta DJ, Chen RF (1997) A major bioploymeric component of dissolved organic carbon in surface sea water. Nature 387:166-169

Asper VL, Deuser WG, Knauer GA, Lorenz SE (1992) Rapid coupling of sinking particle fluxes between surface and deep ocean waters. Nature 357:670-672

Baines SB, Pace ML (1991) The production of dissolved organic matter by phytoplankton and its importance to bacteria: patterns across marine and freshwater systems. Limnol Oceanogr 36:1078-1090

Biddandha B, Benner R (1997) Carbon, nitrogen, and carbohydrate fluxes during the production of particulate dissolved organic matter by marine phytoplankton. Limnol 
Oceanogr 42:506-518

Chin W, Orellana MV, Verdugo P (1998) Spontaneous assembly of marine dissolved organic matter into polymer gels. Nature 391:568-572

Copin-Montégut C, Copin-Montégut G (1983) Stoichiometry of carbon, nitrogen and phosphorus in marine particulate matter. Deep-Sea Res I 30:31-46

Daly KL, Wallace DWR, Smith OS Jr, Skoog R, Gosselin M, Falck E, Yager PL (1999) Non-Redfield carbon and nitrogen cycling in the Arctic: effects of ecosystem structure and dynamics. J Geophys Res C 104(2):3185-3199

Dam HG, Drapeau DT (1995) Coagulation efficiency, organicmatter glues and the dynamics of particles during a phytoplankton bloom in a mesocosm study. Deep-Sea Res II 42: 111-123

Decho AW (1990) Microbial exopolymer secretions in the ocean environments their role(s) in food webs and marine processes. Oceanogr Mar Biol Annu Rev 28:73-153

Drapeau DT, Dam HG, Grenier G (1994) An improved flocculation design for use in particle aggregation experiments. Limnol Oceanogr 39:723-729

Engel A (2000) The role of transparent exopolymer particles (TEP) in the increase in apparent particles stickiness $(\alpha)$ during the decline of a diatom bloom. J Plankton Res 22: 485-497

Engel A (in press) Direct relationship between $\mathrm{CO}_{2}$-uptake and transparent exopolymer particles (TEP) production in natural phytoplankton. J Plankton Res

Engel A, Schartau M (1999) Influence of transparent exopolymer particles (TEP) on sinking velocity of Nitzschia closterium aggregates. Mar Ecol Prog Ser 182:69-76

Engel A, Koeve W, Zeitzschel B (1997) Verteilung Transparenter Exopolymerer Partikel (TEP) im Nordostatlantik Untersuchungen entlang eines $20^{\circ} \mathrm{W}$ Schnittes (Meteor 36/2). Ber Fachbereich Geowiss Universität Bremen 109:23

Hoagland KD, Rosowski JR, Gretz MR, Roemer SC (1993) Diatom extracellular polymeric substances: function, fine structure, chemistry and physiology. J Phycol 29:537-566

Hong Y, Smith WO Jr, White AM (1997) Studies on transparent exopolymer particles (TEP) produced in the Ross Sea (Antarctica) and by Phaeocystis antarcitca (Prymnesiophyceae). J Phycol 33:368-376

Ittekkot V, Brockmann U, Michaelis W, Degens ET (1981) Dissolved Free and Combined Carbohydrates during a Phytoplankton Bloom in the Northern North Sea. Mar Ecol Prog Ser 4:299-305

Kähler P, Koeve W (2001) Marine dissolved organic matter: can its C:N ratio explain carbon overconsumption. DeepSea Res I 48:49-62

Kepkay PE, Jellet JF, Niven SEH (1997) Respiration and the carbon-to-nitrogen ratio of a phytoplankton bloom. Mar Ecol Prog Ser 150:249-261

Kiørboe T, Hansen JLS (1993) Phytoplankton aggregate formation: observation of patterns and mechanisms of cell sticking and the significance of exopolymeric material. J Plankton Res 15:993-1018

Kraus M (1997) Zur Bildung von TEP (transparent exopolymer particles) in der Kieler Bucht. MSc thesis, University of Kiel

Krembs C, Engel A (2001) Abundance and variability of microorganism and TEP across the ice-water interface of melting first-year sea-ice in the Laptev Sea (Arctic). Mar Biol 138:173-185

Leppard GG (1995) The characterization of algal and microbial mucilages and their aggregates in aquatic ecosystems. Sci Total Environ 165:103-131

Logan BE, Passow U, Alldredge AL, Grossart HP, Simon M (1995) Rapid formation and sedimentation of large aggre- gates is predictable from coagulation rates (half-lives) of transparent exopolymer particles (TEP). Deep-Sea Res II 42:203-214

Long RA, Azam F (1996) Abundant protein-containing particles in the sea. Aquat Microb Ecol 10:213-221

Mari X (1999) Carbon content and C:N ratio of transparent exopolymer particles (TEP) produced by bubbling of exudates of diatoms. Mar Ecol Prog Ser 33:59-71

Mari X, Burd A (1998) Seasonal size spectra of transparent exopolymeric particles (TEP) in a coastal sea and comparison with those predicted using coagulation theory. Mar Ecol Prog Ser 163:63-76

Mari X, Kiørboe T (1996) Abundance, size distribution and bacterial colonization of transparent exopolymeric particles (TEP) during spring in the Kattegat. J Plankton Res 18:969-986

Mopper K, Zhou J, Ramana KS, Passow U, Dam HG, Drapeau DT (1995) The role of surface-active carbohydrates in the flocculation of a diatom bloom in a mesocosm. Deep-Sea Res II 42:47-73

Myklestad S (1977) Production of carbohydrates by marine planktonic diatoms. II Influence of the N/P ratio in the growth medium on the assimilation ratio, growth rate and production of cellular and extracellular carbohydrates by Chaetoceros affinis var Willei (Gran) Hustedt and Skeletonema costatum (Grev) Cleve. J Exp Mar Biol Ecol 29: 161-179

Myklestad S, Haug A, Larsen B (1972) Production of carbohydrates by the marine diatom Chaetoderos affinis var Willei (Gran) Hustedt II: preliminary investigation of the extracellular polysaccharide. J Exp Mar Biol Ecol 9:137-144

Myklestad S, Holm-Hansen O, Varum KM, Volcani BE (1989) Rate of release of extracellular amino acids and carbohydrates from the marine diatom Chaetoceros affinis. J Plankton Res 11:763-773

Osteroth A, Wenck A, Kremling K, Gocke K (1985) Concentration of dissolved organic copper in relation to other chemical and biological parameters in coastal Baltic waters. Mar Ecol Prog Ser 22:273-279

Passow U (2000) Formation of transparent exopolymer particles, TEP, from dissolved precursor material. Mar Ecol Prog Ser 192:1-11

Passow U, Alldredge AL (1994) Distribution, size and bacterial colonization of transparent exopolymer particles (TEP) in the ocean. Mar Ecol Prog Ser 113:185-198

Passow U, Alldredge AL (1995) A dye-binding assay for the spectrophotometric measurement of transparent exopolymer particles (TEP) in the ocean. Limnol Oceanogr 40: 1326-1335

Passow U, Wassmann P (1994) On the trophic fate of Phaeocystis pouchetii (Hariot): IV. The formation of marine snow by P. pouchetii. Mar Ecol Prog Ser 104:153-161

Passow U, Shipe RF, Murray A, Pak DK, Brzezinski MA, Alldredge AL (2001) Origin of transparent exopolymer particles (TEP) and their role in the sedimentation of particulate matter. Cont Shelf Res 21:327-346

Pettine M, Patrolecco L, Manganelli M, Capri S, Farrace MG (1999) Seasonal variations of dissolved organic matter in the northern Adriatic Sea. Mar Chem 64:153-169

Ramus J (1977) Alcian Blue: A quantitative aqueous assay for algal acid and sulfated polysaccharides. J Phycol 13: 345-348

Redfield AC, Ketchum BM, Richards FA (1963) The influence of organism on the composition of sea-water. Hill MN (ed) The Sea. Wiley, New York, p 26-77

Sachs L (ed) (1992) Angewandte Statistik. Springer-Verlag, Berlin 
Sakshaug E, Holm-Hansen O (1977) Chemical composition of Skeletonema costatum (Grev.) Cleve and Pavlova (Monochrysis) lutheri (Droop) Green as a function of nitrate-, phosphate-, and iron-limited growth. J Exp Mar Biol Ecol 29:1-34

Schuster S, Arrieta JM, Herndl GJ (1998) Adsorption of dissolved free amino acids on colloidal DOM enhances colloidal DOM utilization but reduces amino acid uptake by orders of magnitude in marine bacterioplankton. Mar Ecol Prog Ser 166:99-108

Shanks AL, Trent JD (1980) Marine snow: sinking rates and potential role in vertical flux. Deep-Sea Res I 27:137-143

Williams PJleB (1995) Evidence for the seasonal accumulation of carbon-rich dissolved organic material, its scale in com-

Editorial responsibility: Otto Kinne (Editor),

Oldendorf/Luhe, Germany parison with changes in particulate material and the consequential effect on net $\mathrm{C} / \mathrm{N}$ assimilation ratios. Mar Chem 51:17-29

Williams PM, Bauer JE, Robertson KJ, Wolgast DM, Occelli ML (1993) Report on DOC and DON measurements made at Scripps Institution of Oceanography, 1988-1991. Mar Chem 41:271-281

Wood MA, Van Valen LM (1990) Paradox lost? On the release of energy-rich compounds by phytoplankton. Mar Microb Food Webs 4:103-116

Zhou J, Mopper K, Passow U (1998) The role of surface active carbohydrates in the formation of transparent exopolymer particles by bubble adsorption of seawater. Limnol Oceanogr 43:1860-1871

Submitted: July 12, 2000; Accepted: January 23, 2001

Proofs received from author(s): August 21, 2001 